\title{
De danske udlandskirker. En religionsdemografisk model for migrantmenigheder
}

\author{
MARGIT WARBURG
}

ENGLISH ABSTRACT: From the perspective of sociology of religion, the Danish churches abroad are similar to other migrant congregations, primarily by caring for broader social and cultural needs among the members of the congregation than what is usually the case in the home country. Abroad, the Danish churches are ethnic minority churches, and I analyse their demographic development on the basis of a new, general model for migrant congregations. On the basis of this model I argue that like other immigrant congregations the Danish churches abroad have to consider the issue of assimilation and the issue of proselytising. These issues are decisive for the longterm survival of the congregations and their position in the Danish model of religion.

DANSK RESUMÉ: Fra et religionssociologisk perspektiv ligner de danske udlandskirker først og fremmest andre migrantmenigheder ved, at de dækker bredere sociale og kulturelle behov blandt menighedens medlemmer, end hvad der normalt er tilfxldet $i$ hjemlandet. I udlandet er de danske kirker etniske minoritetskirker, og deres demografiske udvikling bliver analyseret med udgangspunkt $i$ en ny, generel demografisk model for migrantmenigheder. Ud fra modellen kan man argumentere for, at de danske udlandskirker er tvunget til at forholde sig til nogle helt centrale spørgsmål, som gælder alle migrantmenigheder, nemlig spørgsmålet om assimilation og spørgsmålet om mission. Svarene på disse spørgsmål er afgørende for menighedernes overlevelse på længere sigt og deres placering $i$ den danske religionsmodel.

KEYWORDS: Danish churches abroad; demographics by religion; model of migrant churches; assimilation; church and state 
Organisationen Danske Sømands- og Udlandskirker, forkortet DSUK, er en paraplyorganisation for knap 40 danske menigheder i udlandet. Disse menigheder omtales i almindelighed som danske udlandskirker, og denne betegnelse for de danske udlandsmenigheder vil blive opretholdt, hvor det sprogligt falder naturligt. Rent analytisk er der ingen forskel på betegnelserne udlandskirke og udlandsmenighed.

De danske udlandskirker hører hjemme i den danske religionsmodels grænseflade. Det gør de, fordi de udlandskirker, som er medlem af DSUK, både er en del af folkekirken i Danmark og selvstændige organisationer med egen status i deres værtsland og med selvstændig økonomi.

Foruden de nævnte knap 40 danske udlandsmenigheder er der 30 danske menigheder i Sydslesvig. De sydslesvigske kirker har deres egen organisation under DSUK, og de yder kirkelig betjening til det dansksindede mindretal syd for den nuværende grænse, som blev fastlagt ved Genforeningen i 1920. De sydslesvigske menigheder er således ikke migrantmenigheder i modsætning til de øvrige danske udlandsmenigheder. De sydslesvigske menigheder vil derfor ikke blive omtalt yderligere i denne artikel, som handler om de knap 40 danske DSUK-menigheder i udlandet samt enkelte menigheder, som stadig har et dansk præg, men som ikke er medlemmer af DSUK.

Denne artikel vil indledningsvis kort uddybe de danske udlandskirkers placering i den danske religionsmodels grænseflade. Herefter vil nogle af udlandskirkernes udfordringer blive behandlet med udgangspunkt i teorier for migrantmenigheder generelt. Specielt vil diskussionen dreje sig om de demografiske og sproglige ændringsprocesser, som påvirker alle migrantmenigheder uanset deres religiøse tilhørsforhold. Disse ændringsprocesser bliver analyseret ved hjælp af en ny demografisk model for migrantmenigheder. Modellen forklarer og underbygger et historisk forløb, hvor flere af de danske udlandsmenigheder har flyttet sig eller gradvist flytter sig ud ad religionsmodellens grænseflade for til slut at forlade religionsmodellen helt gennem assimilation i værtslandets lutherske kirkesamfund.

\section{De danske udlandskirker i den danske religionsmodels grænseflade}

DSUK fremstiller sig selv med sloganet: “Vi er folkekirken i udlandet" (Danske Sømands- og Udlandskirker 2014). ${ }^{1}$ Det er dækkende på flere centrale punkter. Først og fremmest er præsterne under gejstligt tilsyn af en af de danske biskopper, hvilket blandt andet betyder, at biskoppen kan gribe ind, hvis præsten i sin forkyndelse afviger for meget fra folkekirkens teologiske grundlag efter biskoppens skøn. Gudstjenester og andre kirkelige handlinger er også underlagt de samme rammer og be-

1 Hjemmesiden indeholder en del af de oplysninger om DSUK, som er gengivet her i artiklen med mindre andre kilder er angivet. De danske udlandskirkers historie er også kort berørt andetsteds (Warburg 2012a; 2012b) 
stemmelser, som gælder for enhver sognekirke i Danmark. Set fra præsteembedets side er en dansk udlandskirke, som er tilknyttet DSUK, derfor en folkekirkelig kirke. ${ }^{2}$

Men præstens perspektiv er ikke enerådende, og fra et religionssociologisk perspektiv er en dansk udlandskirke klart forskellig fra en dansk sognekirke. De danske menigheder i udlandet tilhører nemlig ikke majoritetsbefolkningen i værtslandet, men minoriteten af udvandrede danskere og i nogen udstrækning også deres efterkommere. En dansk udlandskirke kan derfor opfattes som en udvandrerkirke, hvis det analytiske perspektiv er rettet mod forhold i afsenderlandet, og omvendt kan den opfattes som en indvandrerkirke, hvis det er forholdene i modtagerlandet, som er i fokus. Ved at bruge betegnelsen migrantkirke eller migrantmenighed dækkes begge betydninger.

Blandt udlandskirkerne udgør sømandskirkerne en særlig kategori, idet de oprindeligt blev oprettet primært for at betjene danske søfolk i fremmede havne. Selv om de stadig udfylder denne opgave, er de fleste sømandskirker i dag også kirker for en fastboende menighed af danskere, hvad enten de er udstationerede for en årrække eller permanent udvandret (Warburg 2012b). Denne udvikling var et hovedmotiv for dannelsen af DSUK i 2004 ved en sammenlægning mellem organisationerne Dansk Kirke i Udlandet og Dansk Sømandskirke i fremmede Havne.

Det empiriske materiale til denne artikel stammer primært fra egne feltbesøg med deltagerobservation, interviews og indsamling af skriftligt materiale blandt danske udlandskirker i Argentina, Australien, Belgien, Canada, England, Grækenland, Luxembourg, Nederlandene, Singapore, Tyskland og USA. Derudover har jeg benyttet mig af data fra en stor spørgeskemaundersøgelse med besvarelser fra over tusind danskere bosat i udlandet, Religion blandt danskere $i$ udlandet 2009 (Jacobsen \& Warburg 2011).

\section{De danske udlandskirker er etniske kirker}

Adskillige religionssociologiske undersøgelser af de migrantgrupper, som tilhører en majoritetsreligion i deres hjemland, har vist, at migranterne ofte fravælger at tilslutte sig eksisterende menigheder af samme trosretning i det nye værtsland - i stedet foretrækker de at organisere sig i menigheder efter etnisk eller nationalt tilhørsforhold (Warner 1998a; 1998b; Yang \& Ebaugh 2001; Ballard 2003; Levitt 2007). Sådan er det også i Danmark, hvor der for eksempel er etniske indvandrermenigheder som Den rumænsk ortodokse menighed i Charlottenlund, Den Forenede Vietnamesiske Buddhistiske Forening i Odense og naturligvis de klassiske national-etniske kirker i København som St. Alban's English Church og Svenska Gustafsförsamlingen. Dertil kommer de mange danske muslimske menigheder, som har organiseret sig efter de

2 Udlandskirkernes tilhørsforhold til folkekirken fremhæves også på folkekirkens egen hjemmeside, http://www.folkekirken.dk/folkekirkens-arbejde/dansk-kirke-i-udlandet/ (set 15. november 2014). 
muslimske indvandrers etniske baggrund (Kühle 2006). Helt tilsvarende forholder det sig for danskerne i udlandet - deres kirker er etniske kirker.

Sproglige hensyn vejer tungt ved oprettelsen af de etniske migrantkirker, for når gudstjenesten afholdes på hjemlandets sprog skabes en vigtig, institutionaliseret sproglig og kulturel forbindelse tilbage til hjemstavnen. Denne institutionelle forbindelse til hjemlandet kan som regel ikke skabes i private klubber og foreninger i samme grad og med samme vægt. Samtidig tilbyder migrantkirkerne et muligt fælles mødested for alle immigranter, også de nytilkomne, som her får lejlighed til at etablere kontakter og venskaber, som kan hjælpe dem til lettere at etablere sig i det nye værtsland. Migrantkirkerne danner ofte en bred ramme om forskellige selskabelige arrangementer, sprogundervisning og lignende, foruden selvfølgelig afholdelse af gudstjenester og de dertil knyttede aktiviteter (Ebaugh \& Chafetz 2000, 71-79; Yang \& Ebaugh 2001).

Mange undersøgelser af migrantmenigheder har været rettet mod asiatiske og latinamerikanske (Hispanic) immigranter i USA, og disse grupper er ofte socialt og økonomisk ringere stillet end den amerikanske befolkning generelt. Historisk gjaldt det også i nogen grad de danske immigranter - især var udvandrerne fra landområderne fattige (Hvidt 1971, 237-240; Simonsen 1990, 20-21). Men fattigdom præger ikke længere de danske udvandrere - i dag udvandrer danskerne af lyst, ikke af nød, og mange tilhører en privilegeret klasse i det nye værtsland (Warburg 2012a). Alligevel genfinder man mange træk i de danske migrantmenigheder, som er fælles for migrantmenigheder generelt.

Ligesom andre migrantkirker opfylder de danske kirker i udlandet ikke bare et behov blandt udlandsdanskerne for at kunne gå til en evangelisk-luthersk gudstjeneste med dansk liturgi; de danske kirker fungerer også som sociale samlingssteder, hvor man kan mødes med andre danskere, købe danske specialiteter - især lakrids er populært - og udveksle erfaringer og gode råd om, hvordan det er at være dansk i udlandet. At mødes i kirken giver udlandsdanskerne flere sociale ressourcer, som gør det lettere for dem at begå sig i et samfund, hvor de ikke tilhører majoriteten (Warburg 2012a; 2013). Udlandsdanskernes danske identitet styrkes også ved at holde jul på dansk manér, og de danske udlandskirkers traditionsrige julebasarer besøges af mange lokale udlandsdanskere (Jacobsen \& Warburg 2013). Adskillige kirker arrangerer desuden sprogundervisning for børn og ikke-danske ægtefæller, og familien sikrer blandt andet derved, at børnene kan tale med deres bedsteforældre i Danmark. Det gælder for eksempel de danske kirker i Sydney, Singapore, Bruxelles, Rhodos og London. ${ }^{3}$

Det skal understreges, at det kun er et beskedent mindretal af de udvandrede danskere, som er medlemmer af en dansk kirke i udlandet, på trods af at langt ho-

3 Data fra feltbesøg i februar 2007 (Sydney), august 2008 (Singapore), september 2009 (Bruxelles), marts 2011 (Rhodos) og april 2013 (London). 
vedparten givetvis var medlemmer af folkekirken, dengang de boede i Danmark. En kort overslagsberegning understøtter denne påstand:

DSUK (bortset fra Dansk Kirke i Sydslesvig) tæller i skrivende stund (oktober 2014) ca. 40 danske menigheder i udlandet, hvoraf omkring 25 menigheder har egen kirkebygning. ${ }^{4}$

Fra mine besøg i udlandskirkerne ved jeg, at de har nogle få hundrede og i enkelte tilfælde måske op til 500 betalende medlemmer eller mere, men modsat er der også steder, hvor man har under 100 medlemmer.

Hvis man antager, at hver af de ca. 25 menigheder med egen kirke har 400 betalende medlemmer, og hver af de øvrige ca. 15 menigheder har 100 betalende medlemmer, så er det maksimale antal betalende medlemmer 11.500 i alt. Da tallet givetvis er meget i overkanten, skønner jeg, at der samlet højst kan være 10.000 betalende medlemmer af de danske udlandskirker, som er tilknyttet DSUK.

Da der skønsmæssigt er over 200.000 danske statsborgere bosat i udlandet (Warburg 2012b), viser denne overslagsberegning, at under 5 pct. af udlandsdanskerne er medlem af en dansk kirke i udlandet. Tallet dækker dog over store lokale forskelle; for eksempel har størstedelen af de danske familier bosat i Singapore gjort brug af den danske sømandskirke (Warburg 2012a). Netop denne kirke fungerer helt oplagt som det centrale sociale mødested for de fleste danskere i Singapore i overensstemmelse med, hvad man kunne forvente ud fra forskningen i migrantmenigheder generelt (Warburg 2013).

En indlysende årsag til den generelt beskedne opslutning om udlandskirkerne er selvfølgelig, at danskerne bor spredt og ofte ikke i nærheden af en dansk kirke, hvis der da overhovedet er en dansk kirke i det pågældende land (Jacobsen \& Warburg 2013). En anden vigtig årsag er, at udvandrernes eventuelle medlemskab af folkekirken ikke automatisk overføres til en relevant dansk udlandskirke. Faktisk er det en omstændelig og noget bureaukratisk procedure for de udlandsdanskere, som er skattepligtige i Danmark at få overført den betalte kirkeskat til den udlandskirke, som de måtte ønske at være medlem af (Warburg 2012b).

Der er for så vidt ikke noget nyt i, at det er svært at få udlandsdanskerne til at flokkes om at være medlemmer af de danske kirker. Historikeren Kristian Hvidt anførte i sin disputats om den danske udvandring til USA 1868-1914, at der i perioden 1900-1906 kun var lidt over 25 pct. af de danskfødte amerikanere, som frekventerede en af de danske kirker, mens andelen var 75 pct. for de norskfødte amerikanere (Hvidt 1971, 315-316). Der kan spekuleres meget over årsagerne til den relativt lave tilslutning til de danske kirker i USA, men langvarige stridigheder mellem grundtvigianere og Indre Mission blandt de dansk-amerikanske kirkesamfund har afgjort ikke virket fremmende for det kirkelige arbejde (Hvidt 1971, 316-317; Simonsen 1990,

4 I følge DSUK er der 21 menigheder i Europa, 6 i Canada, 2 i USA, hvoraf kirken i Californien ikke er medlem af DSUK, 4 i Argentina og 6-9 i den øvrige verden, alt efter hvordan man opgør antallet (Danske Sømands- og Udlandskirker 2014). I alt er der således ca. 40 danske menigheder rundt om i verden, hvoraf ca. 25 har egen kirke (Danske Sømands- og Udlandskirker 2014). 
71-88). Dertil kom, at de danske indvandrere boede mere spredt over de forskellige stater end indvandrerne fra stort set alle andre europæiske nationer (Hvidt 1971, 310313).

\section{Generationernes forskellige behov}

Sproget er en afgørende faktor for en migrantmenigheds trivsel. Det er især førstegenerationsindvandrere, som af sproglige og kulturelle grunde føler et behov for at have deres egne menigheder i stedet for at vælge at blive medlem i en stedlig menighed af samme trosretning (Mullins 1987; Ebaugh \& Chafetz 2000, 100-119). Allerede for anden generation er det langt fra en selvfølge at tilslutte sig forældrenes kirke, og det gælder ikke mindst, hvis de har giftet sig med en person uden for deres egen etniske minoritetsgruppe.

I de migrantmenigheder hvor man ønsker at fastholde anden og tredje generation i menigheden, er man derfor typisk stillet over for et behov for også at gennemføre gudstjenester på værtslandets sprog (Mullins 1987). Næsten alle migrantkirker står i et dilemma mellem at varetage første generations ønsker om at bruge hjemlandets sprog i kirken over for anden og tredje generations behov for kirkegang og samvær på værtslandets sprog. Disse spændinger mellem generationernes forskellige ønsker og behov er en væsentlig faktor i migrantmenighedernes demografiske udvikling og deres udsigt til at kunne bevare deres etniske særpræg.

De seks danske kirker i Canada er illustrative eksempler på betydningen af generationernes forskelligartede og ofte modstridende forventninger til deres etniske migrantkirke. I lighed med dansk-amerikanerne i første halvdel af 1900-tallet assimileres efterkommerne af danske indvandrere i Canada i dag let ind i det canadiske majoritetssamfund, og de gifter sig som regel med andre canadiere med ikke-dansk baggrund. Men selv om ægtefællen ofte også er protestant, så er sproget en barriere i valget mellem at tilslutte sig en dansk luthersk menighed i Canada frem for en stedlig canadisk, engelsksproget luthersk menighed. Og her er udbuddet rigeligt. Pastor Carl-Gustav Christensen i den danske kirke i Edmonton gav følgende forklaring på, hvorfor anden generations dansk-canadiere ikke kom i den danske kirke:

Det skyldes, at de shopper rundt efter den rigtige kirke for dem. Og der er mange kirker i Edmonton at vælge imellem. Faktisk er den vej, som den danske kirke ligger på, med i Guinness Book of Records som den vej i verden, hvor der er flest kirker! Så det er svært at finde en parkeringsplads om søndagen (Interview den 11. juni 2009).

Der kommer heller ikke særlig mange nye danske indvandrere til Edmonton, selv om den er en hastigt voksende storby og delstaten Albertas hovedstad. Så hvis kirken i Edmonton skal overleve på længere sigt, bliver det sandsynligvis som medlem af Canadian Lutheran Church. Det betyder, at menigheden må opgive sin særlige danske karakter, først og fremmest gudstjenester på dansk, sådan som det også skete 
med de danske kirker i USA fra omkring 1950 og frem. Efter megen diskussion og strid om det danske sprogs betydning, især blandt de grundtvigske menigheder, opgav de dansk-amerikanske kirker til slut at opretholde deres danske særpræg og sluttede sig sammen med de svenske, norske og tyske evangelisk-lutherske trossamfund i en amerikansk, luthersk kirke (Simonsen 1990, 211-229).

Den californiske by Solvang nord for Santa Barbara er berømt for at reklamere med sin danske oprindelse og holde den i hævd. Solvang blev grundlagt som dansk koloni i 1911, og indbyggerne var hovedsagelig dansk-amerikanske farmere fra Midtvesten (Simonsen 1990, 169-172). Kirken, Bethania Lutheran Church, er fra 1928 og opført i dansk middelalderkirkestil, hvidkalket og med trappegavle. Der er stadig omkring tusind mennesker i Solvang, som mere eller mindre behersker dansk, men dansk er ikke noget hverdagssprog i Solvang. ${ }^{5}$ Der er heller ikke længere nogen dansk præst i Solvang, og der afholdes nu kun én dansk gudstjeneste om året, nemlig lillejuleaften. ${ }^{6}$ Kirken i Solvang må i dag siges at være gledet ud af den danske religionsmodel, da den ikke længere er folkekirkelig eller har nogen anden formel tilknytning til Danmark. At Solvang fortsat dyrker byens danske oprindelse giver ikke kirken i Solvang nogen formel forbindelse til Danmark og den danske folkekirke.

Californien er også hjemsted for en anden dansk-amerikansk kirke. Det er Danish Church \& Cultural Center in California, som ligger i Yorba Linda, en velhavende forstad til Los Angeles. Kirken blev grundlagt i 1906 og flyttede i 1990'erne fra det centrale Los Angeles til Yorba Linda i en nybygget kirke. Ligesom kirken i Solvang er kirken bygget som en efterligning af en klassisk dansk landsbykirke. Der er også tilknyttet en forsamlingssal, og udenfor er der en kopi af den store Jellingsten. Menigheden består for halvdelens vedkommende af danske indvandrere, som kom i 1940'erne og 1950'erne, mens den anden halvdel er yngre familier. 25-30 pct. af ægteparrene i menigheden er blandede dansk-amerikanske.

Menigheden i Yorba Linda valgte for nogle år siden at forlade DSUK og i stedet søge tilknytning til en liberal evangelisk-luthersk synode under Evangelical Lutheran Church of America. Ifølge præsten i Yorba Linda ønsker menigheden, at kirken med tiden bliver en amerikansk luthersk kirke, som kan konkurrere med de øvrige kirker i lokalsamfundet. Samtidig ønsker både menigheden og præsten at opretholde et dansk islæt og en grundtvigsk forståelse af menighedslivet som særkende. ${ }^{7}$ Kirken har relativt meget succes, idet den har 800 betalende medlemmer, og kirkebladet bliver udsendt til 1500 husstande - det er efter min vurdering et af det største antal medlemmer, som en dansk udlandskirke kan mønstre. Kirken har samtidig stadig gode forbindelser til det officielle Danmark, for eksempel kom den danske ambassa-

$5 \quad$ Notater fra besøg i Solvang den 17. november 2011.

6 Den sidste danske præst i Solvang var A. Ejnar Farstrup, som gik af i 1980. Kirken arrangerer hvert år The Farstrup-Mortensen Lectures, som er præget af en dansk-amerikansk grundtvigsk højskoletradition (Simonsen 1990, 232; http://www.bethanialutheran.net/education/ (set 15. november 2014). Det er præsten fra den dansk-amerikanske menighed i Yorba Linda, Sydcalifornien, der forretter gudstjenesten lillejuleaften.

7 Interview med pastor Anne-Grethe Krogh Nielsen den 13. og 14. november 2011. 
dør på besøg i 2013, og prins Joachim var gæst ved kirkens hundredårsjubilæum i 2006. Det betyder efter min vurdering, at kirken stadig indgår i den danske religionsmodel, for den bliver set af det officielle Danmark og i øvrigt også af DSUK, som en dansk udlandskirke. 8 Men den befinder sig længere ude i grænsefladen end de øvrige udlandskirker, fordi præsten ikke længere er under tilsyn af en biskop i folkekirken.

\section{En demografisk model for migrantmenigheder}

De foregående eksempler fra kirkerne i Edmonton, Solvang og Yorba Linda illustrerer betydningen af generationsskifte og sproglige præferencer $\mathrm{i}$ en migrantmenigheds udvikling mod assimilation. Kirken i Solvang har i dag lagt den tid bag sig, hvor menigheden bestod af første og anden generations dansk-amerikanere. Derimod har kirkerne i Edmonton og Yorba Linda stadig en aktiv kerne af danske immigranter. I Yorba Linda sigter menigheden bevidst mod assimilation, mens menigheden i Edmonton endnu ikke synes at have anlagt nogen langsigtet strategi for fremtiden. ${ }^{9}$

Som nævnt vil jeg foreslå og opstille en model for migrantmenigheders demografiske sammensætning og udvikling gennem tre idealtypiske stadier. Min model kan bruges til at analysere en udvikling, som de tre nævnte kirker og mange andre danske udlandskirker repræsenterer, og den er ikke bare gyldig for de danske udlandskirker men for migrantmenigheder generelt. Modellen er inspireret af Mark Mullins' (1987) analyse af assimilationstendenser blandt forskellige japanske migrantmenigheder i Canada og hans tre stadier af assimilation, men modellen tager grundlæggende udgangspunkt i mine egne religionsdemografiske analyser af de forskellige bevægelser ind og ud af en religiøs gruppe (Warburg 2006, 264-282). Modellen, som er vist i Figur 1, viser en menigheds udvikling gennem tre stadier, og den angiver de forskellige mekanismer, som styrer medlemmernes til- og afgang fra menigheden (Warburg 2006, 266-268). Hvert af de tre stadier er symboliseret med et rektangel, som er opdelt i vandrette felter. Felternes forskellige gråtone og bredde symboliserer den demografiske sammensætning af menigheden og deres indbyrdes relative størrelse. Modellen bliver nærmere gennemgået nedenfor, og den demografiske dynamik bliver derefter illustreret med eksempler fra forskellige danske udlandskirker.

8 DSUK's hjemmeside henviser til kirken i Yorba Linda med ordene: "Kirken er ikke en del af DSUK, men vi henviser gerne til", efterfulgt af alle de oplysninger, som står om de øvrige danske udlandskirker (http://www.dsuk.dk/vores-kirker/nordamerika/ (set 15. november 2014)).

9 Interview med pastor Carl-Gustav Christensen den 11. juni 2009. 
Figur 1. En demografisk model for migrantmenigheder - eksemplificeret med danske udlandsmenigheder

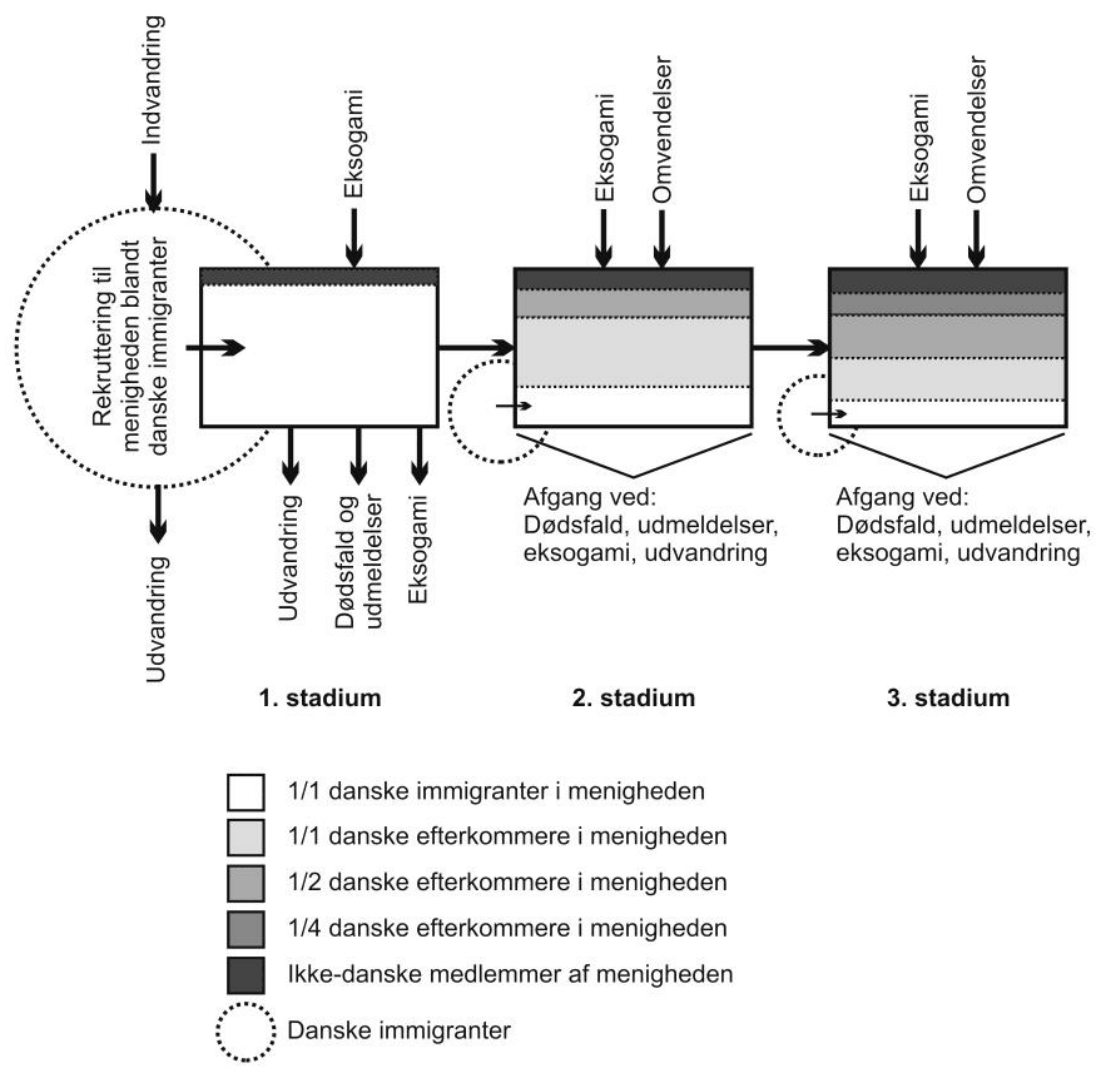

Første stadium er normalt præget af en væsentlig indvandring til værtslandet, og migrantmenigheden domineres af de nye indvandrere, som tilslutter sig menigheden. Mange af dem gifter sig indbyrdes, men nogle finder en ikke-dansk ægtefælle, som vælger at blive medlem af menigheden. Denne lille gruppe af ikke-danske ægtefæller er symboliseret ved det mørke felt øverst i rektanglet. Som vist i bunden af rektanglet er der også nytilkomne indvandrere, som senere forlader menigheden gennem migration, død eller udmeldelse. Nogle af disse udmeldelser skyldes, at de pågældende danske medlemmer vælger at følge med en ikke-dansk ægtefælle over i hendes eller hans kirkesamfund. Eksogami er i det hele taget en betydningsfuld faktor i den demografiske udvikling af migrantmenigheder.

Det stiplede cirkulære felt helt til venstre på modellen, "Rekruttering til menigheden blandt danske immigranter", symboliserer de mange indvandrere, som er potentielle medlemmer af migrantmenigheden. Indvandring betyder nemlig ikke, at kirken automatisk får nye medlemmer. Faktisk er det typisk, at mange indvandrere 
aldrig nogensinde kommer i nærmere kontakt med 'deres' stedlige migrantkirke. Som omtalt tidligere forholder det sig sådan, at danske udvandrere, som er medlemmer af folkekirken, ikke automatisk bliver tilknyttet en relevant dansk kirke i udlandet. Desuden er det de færreste, som af sig selv og som noget af det første kontakter den stedlige danske kirke, når de er flyttet til et nyt land for at bosætte sig. For at udnytte det potentiale for nye medlemmer, som gruppen af immigranter udgør, er mange migrantkirker aktivt engagerede $\mathrm{i}$ at rekruttere nye medlemmer blandt migranterne fra hjemlandet. Det kan også udtrykkes sådan, at de bedriver mission blandt deres egne. Denne problemstilling vender jeg tilbage til i slutningen af artiklen.

I 2. stadium udgøres kernen i en migrantmenighed typisk af efterkommere, hvis forældre begge havde samme etniske baggrund - i figuren betegnet som 1/1 danske efterkommere. Nogle af børnene fra de blandede ægteskaber i 1. stadium forbliver medlemmer af menigheden, og disse 1/2 danske efterkommere udgør sammen med de ikke-danske medlemmer en voksende gruppe af medlemmer, som ikke har dansk som førstesprog. De er derfor med til at stille krav om gudstjenester også på værtslandets sprog, som omtalt før (Mullins 1987). Det forekommer også, at nogle få ikkedanskere bliver medlemmer af kirken på anden måde end gennem ægteskab. Det sker typisk ved at de kender nogen i menigheden og efterhånden bliver glade for komme til kirkens gudstjenester og andre arrangementer. Det er angivet som "omvendelser", men ofte kunne det også betegnes som "denominationsskifte", sådan som man kender det fra USA blandt de mange forskellige protestantiske kirkeretninger.

I 2. stadium foregår der stadig en vis indvandring af danskere, og derfor rekrutteres der fortsat medlemmer af menigheden, som har dansk som førstesprog. Denne situation vil menigheden typisk håndtere ved, at nogle gudstjenester holdes på dansk, andre på værtslandets sprog. De salmer, der synges ved de ikke-danske gudstjenester, vil ofte være oversatte udgaver af kendte salmer fra Den Danske Salmebog, og de synges på de oprindelige melodier.

I 3. stadium er de medlemmer, som har dansk som førstesprog, klart i mindretal, og mange medlemmer er ikke længere dansktalende til daglig. Selv blandt $1 / 1$ danske efterkommere i tredje generation er der mange, som ikke behersker dansk særlig godt - undtagelsen herfra er de danske menigheder i Argentina, som jeg vil omtale senere. I 3. stadium er det hovedreglen, at gudstjenesterne afholdes på værtslandets sprog, men det er typisk, at man beholder et par salmer og ind imellem også en hel gudstjeneste på dansk, så den danske forbindelse stadig er til stede.

Efter 3. stadium er menigheden assimileret, og den har stort set ikke noget dansk særpræg længere, eller også er den opløst af mangel på medlemmer.

Det er langt fra alle danske udlandsmenigheder, som kan forvente at gennemgå en udvikling frem mod 2. og 3. stadium, hvor også anden, tredje og efterfølgende generationer er vigtige i menigheden. Tre forskellige eksempler på danske udlands- 
kirker, som formodentlig ikke udvikler sig ud over 1. stadium, er sømandskirken i Singapore, den lille menighed på Rhodos og den canadiske menighed i Surrey uden for Vancouver.

Kirken i Singapore betjenes af en fast udstationeret dansk sømandspræst, og menigheden består først og fremmest af udstationerede danskere med deres familier. Menigheden er således helt domineret af første generation, og der er stort set ingen eksogami. Jeg har mødt én dansker - en selvstændig forretningsmand, som blev gift med en singaporeaner, og han er blevet hængende, som han sagde. ${ }^{10}$ Med ganske få undtagelser er der ingen af de danske familier, der forventer at emigrere permanent, og langt hovedparten af menigheden udvandrer derfor igen, så 2. og 3. stadium findes ikke. Men kirken er levedygtig, for der er hele tiden en tilstrømning af nye danske immigranter til erstatning for dem, der rejser tilbage til Danmark eller videre i verden. ${ }^{11}$ Denne kirke kan derfor forventes fortsat at indgå i den danske religionsmodels grænseflade.

Menigheden på Rhodos er for lille til at have en fast dansk præst. I stedet tager en præst tilknyttet DSUK til Rhodos tre gange om året for at afholde gudstjeneste og øve sjælesorg. Menigheden består næsten udelukkende af danske kvinder, der som unge blev gift med en lokal græker. Eksogami er således det dominerende ægteskabsmønster, og disse kvinders børn er halvt etnisk danske og kunne teoretisk udgøre en stor del af menigheden og videreføre den i 2. stadium. Men de indvandrede kvinders græske mænd har ingen interesse $\mathrm{i}$ at være medlemmer af en lille dansk protestantisk kirke - de og deres familier er ortodokse, og der er ofte et stort pres fra den græske del af familien for, at børnene bliver ortodokst døbt. Så gruppen af efterkommere er næsten helt fraværende, i hvert fald som voksne. Der bosætter sig ikke ret mange nye danskere på Rhodos, så der er stort set ingen ny tilgang til menigheden. Menigheden på Rhodos kan næppe undgå at blive opløst, når den nuværende gruppe af danske kvinder ikke mere kan opretholde menighedslivet. Dermed vil den forsvinde ud af den danske religionsmodel.

I Surrey i British Colombia, Canada, består menigheden i stor udstrækning af danske indvandrere, som er ressourcestærke, men også ret få. En pensioneret dansk præst, der er udsendt af DSUK, er fast tilknyttet kirken, og omkostningerne dækkes fuldt ud af menigheden. Her er situationen, at man tilsyneladende ikke har prioriteret fastholdelsen af anden generation, hvilket måske nok også er det mest realistiske valg, da menigheden næppe har et tilstrækkeligt demografisk grundlag for at kunne overleve 1. stadium. Dermed vil kirken glide ud af den danske religionsmodel.

Den demografiske dynamik i 2. stadium og 3. stadium er kritisk for menighedens overlevelse på længere sigt. Efterkommernes forbliven i menigheden afhænger meget af, om de gifter sig indbyrdes eller med lokale, altså om der er endogami eller

10 Interviews den 24. - 26. august 2008.

11 Det er de samme religionsdemografiske forhold, der gør sig gældende for den neo-pentekostale migrantmenighed, som tiltrækker mange filippinske au-pair piger i Københavnsområdet; se Trolles artikel i dette nummer. 
eksogami. Eksogami kan som nævnt føre til, at ægtefællen udefra slutter sig til menigheden, og parrets børn fødes ind i menigheden - det er der mange eksempler på, blandt andet i London og i Rotterdam. Men eksogami kan også medføre, at medlemmerne forlader menigheden for at tilslutte sig ægtefællens menighed, og deres børn vil så ikke blive født ind i den danske menighed. At fastholde den halvt etniskdanske anden generation i et aktivt menighedsliv er imidlertid en betydelig udfordring.

Betydningen af ægteskabsmønsteret er også en af de faktorer, der forklarer, hvorfor de danske kirker i Argentina har kunnet bevare deres danske særpræg i flere generationer. I de oprindelige dansk-argentinske landbofamilier var der et betydeligt socialt pres for, at man skulle gifte sig med andre dansk-argentinere (Harritshøj 2007; Møller 2007, 79). Også på andre måder søgte dansk-argentinerne at undgå assimilation; for eksempel gjorde familierne ofte meget ud af at kræve af børnene, at de talte dansk og ikke spansk i hjemmet, for man ønskede ikke at høre "de sortes" sprog inden døre (Møller 2007, 86).

At de danske kirker i Argentina har kunnet bevare deres etniske særpræg så længe, hænger nok også sammen med, at Argentina er et katolsk land. Det udgør formodentlig en større barriere mod, at medlemmerne af de danske kirker skifter kirkeligt tilhørsforhold end i det overvejende protestantiske Canada. I forbindelse med blandede ægteskaber har det i øvrigt været et aktiv for den danske kirke, at den som protestantisk kirke har kunnet tilbyde fraskilte argentinere en mulighed for at blive gift kirkeligt igen, hvis de konverterede.

Fertiliteten har selvsagt også stor betydning for den demografiske udvikling, idet en religiøs gruppe ikke kvantitativt kan reproducere sig selv, hvis fødselsraten er sammenlignelig med de industrialiserede landes fødselsrater i dag med omkring to børn per kvinde eller derunder. Gruppen kan kun opretholde sin størrelse, hvis den også får tilført nye medlemmer udefra. Den etniske migrantmenighed er derfor dømt til at tabe medlemmer og miste sin etniske karakter, med mindre der er en stabil tilstrømning af nye indvandrere af samme etniske baggrund. Nye medlemmer erhvervet gennem omvendelse er ikke et alternativ til at rekruttere medlemmer blandt indvandrerne, hvad angår den etniske profil af menigheden - tværtimod fortyndes dens særlige etniske karakter.

\section{Migrantmenighedernes dilemma}

Indvandring sker i bølger, som afhænger af forhold i både afsenderlandet og modtagerlandet, og i almindelighed vil tilstrømningen af nye immigranter til modtagerlandet svækkes eller næsten ophøre efter en årrække (Portes \& Böröcz 1989). Ud fra den demografiske model og min efterfølgende diskussion kunne man konkludere, at den demografiske udvikling før eller siden vil stille mange migrantmenigheder over for et helt generelt dilemma: Hvis de fastholder deres etniske særpræg, må de se i øjne- 
ne, at de ikke kan opretholde menigheden i længden, fordi de fleste efterkommerne assimileres og forlader menigheden, samtidig med at det demografiske grundlag for at rekruttere nye medlemmer blandt indvandrerne ikke længere eksisterer i samme omfang som tidligere. Hvis de derfor ønsker at bevare menigheden, må de bevidst assimilere sig og opgive deres etniske særpræg. Det var udviklingen for de mange danske kirker i præriestaterne i USA, og det er sandsynligvis også, hvad der vil ske for flere af kirkerne i Canada og Argentina, idet tilstrømningen af danske immigranter til disse kirkers opland stort set er ophørt. Disse kirker er, hvad man kan kalde klassiske danske udvandrerkirker. De blev grundlagt af en bølge af danske udvandrere, som havde intentioner om at etablere sig i USA, Argentina og Canada, og som forventede, at de og deres efterkommere ville kunne skabe sig en bedre tilværelse i det fremmede.

Situationen er noget anderledes for de globaliserede storbykirker, som sømandskirken i Singapore er et godt eksempel på. Den er primært en kirke for nutidens professionelle arbejdsmigranter. Det gælder også kirkerne i for eksempel Bruxelles og Luxembourg. Menighederne her udgøres primært af danske statsborgere, som nok har et langvarigt ophold i landet, men som ikke har planer om at blive der resten af deres liv.

Man må regne med, at gruppen af langvarigt udstationerede danskere vil vokse fremover på grund af globaliseringen. Men det er dog ikke bare arbejde, der motiverer danskere til at udvandre. I spørgeskemaundersøgelsen fra 2009 Religion blandt danskere $i$ udlandet spurgte vi blandt andet om årsagerne til udvandring (Jacobsen \& Warburg 2013). Mens 47 pct. af respondenterne anførte "arbejde" som hovedårsagen til, at de udvandrede, angav 24 pct. "kærlighed" som grund. Her er det rimeligt at antage, at denne kærlighed i de fleste tilfælde har ledt til indgåelse af et etnisk blandet ægteskab, og at den danske partner må forventes at være permanent udvandret. De etnisk blandede familier i udlandet kunne være en målgruppe for de danske udlandskirker. Udfordringen er her, at de fast bosiddende, etnisk blandede familier givetvis har nogle andre ønsker til, hvad kirken skal tilbyde, end de udstationerede danske familier, som normalt har en forventning om at vende tilbage til Danmark.

Migrantmenigheders dilemma mellem at uddø eller assimileres understreger, hvor afgørende det er for de danske udlandskirkers beståen på langt sigt, at de bedriver effektiv mission blandt de tilvandrede danskere. Det er langt de fleste danske udlandskirker også opmærksomme på. Christianskirken i Berlin har for eksempel gjort en stor indsats for at få fat i de mange unge danskere, som bor i kortere eller længere tid i Berlin. Det er også lykkedes ganske godt, men indsatsen hæmmes af den stramme økonomi og af, at kirken heller ikke ligger tæt ved de kvarterer i Berlin, hvor de unge først og fremmest bosætter sig. ${ }^{12}$ 


\section{Konklusion}

De danske udlandskirker af i dag står over for nogle demografiske udfordringer, som er ret forskellige, alt efter kirkernes historiske baggrund. De klassiske danske udvandrerkirker, som først og fremmest er repræsenteret af kirkerne i provinsområderne i Canada og Argentina, har alle det problem, at tilstrømningen af nye immigranter fra Danmark stort set er ophørt. Det gør det vanskeligt for dem i længden at opretholde den særlige danske tilknytning og det danske sprog. Langt hovedparten af medlemmerne af disse kirker er ikke danske statsborgere, og det er begrundelsen for, at disse kirker ikke får statsstøtte gennem DSUK, men må nøjes med frivillige bidrag fra DSUK's medlemmer og lejlighedsvise kollekter, foruden naturligvis menighedernes egne bidrag (Warburg 2012b). Enkelte af udvandrerkirkerne vil lukke, mens andre vil overleve. De vil dog kun overleve, hvis de vælger en assimilationspolitik, hvor de bliver medlemmer af et større, tvær-etnisk, protestantisk kirkesamfund. I løbet af denne proces bevæger disse menigheder sig fra den danske religionsmodels grænseflade og udad, indtil de ikke længere udgør en etnisk minoritet med forbindelse til den danske stat og den danske folkekirke, men udelukkende forholder sig til det stedlige majoritetssamfund. Den danske kirke i Yorba Linda og den tidligere danske kirke i Solvang er markante eksempler på denne udvikling. Som nævnt ligger kirken i Yorba Linda længere ude i religionsmodellens grænseflade end de øvrige udlandskirker, mens kirken i Solvang ikke længere kan siges at høre hjemme i religionsmodellen.

Med globaliseringen og den stærkt stigende velstand i Danmark siden 1960'erne, kan man forudse, at masseudvandring fra Danmark hører fortiden til, hvorimod antallet af migranter, som bosætter sig i udlandet i en årrække for derefter at vende hjem, vil stige. Det kan give grundlag for etablering af nye kirker, som især retter sig mod de midlertidige udvandrere og deres familier.

De globaliserede storbykirker, hvortil også hører hovedparten af sømandskirkerne, er karakteriseret ved, at de fleste af deres medlemmer er danskfødte indvandrere, der som regel har bevaret deres danske statsborgerskab. Det er det danske statsborgerskab, som er grunden til, at disse kirker får statsstøtte (Warburg 2012b). Sammenlignet med de klassiske udvandrerkirker er storbykirkerne placeret længere ind mod centrum i den danske religionsmodel. Men de er dog stadig i dens grænseflade, for menighederne hører ikke organisatorisk til folkekirken, selv om præsterne er under tilsyn af en af folkekirkens biskopper.

Udfordringerne for de globaliserede storbykirker er især at få bedre kontakt med de nye danske arbejdsmigranter, som ofte kun er på midlertidigt ophold. Det er disse danske migranter, som skal sikre tilstrømningen af nye medlemmer til disse kirker, hvis de skal bevare deres karakter af danske udlandskirker. Denne udfordring må betragtes som en missionsopgave blandt de stedlige udlandsdanskere, og det er måske en lidt fremmed tankegang i folkekirken, hvor man traditionelt ikke har forventet, at præst og menighed skal missionere blandt andre danskere. Men det er altså 
de demografiske betingelser, hvis man som udlandskirke er placeret i den danske religionsmodels grænseflade og har et ønske om at overleve på længere sigt.

\section{LITTERATUR}

Ballard, Roger

2003 "The South Asian presence in Britain and its transnational connections", in: Bhikhu Parekh, Gurharpal Singh \& Steven Vertovec, eds., Culture and Economy in the Indian Diaspora, Routledge, London, 197-222.

Danske Sømands- og Udlandskirker

2014 Om DSUK, http://www.dsuk.dk/om-dsuk/ (set 7.3.2014).

Ebaugh, Helen Rose \& Janet Saltzman Chafetz

2000 Religion and the New Immigrants: Continuities and Adaptations in Immigrant Congregations, AltaMira Press, New York.

Harritshøj, Rune Vitus

2007 "Danskerne i Argentina", in: Adil Erdem, ed., Indvandrernes paradis - danske rødder i Argentina, Geografforlaget, København, 8-21.

Hvidt, Kristian

1971 Flugten til Amerika eller Drivkræfter i masseudvandringen fra Danmark 1868-1914, Universitetsforlaget i Aarhus, Aarhus.

Jacobsen, Brian A. \& Margit Warburg

2011 “... og dog så vidt om jorden: Udlandsdanskere sammenlignet med danskere i Danmark”, in: Peter Gundelach, ed., Små og store forandringer. Danskernes værdier siden 1981, Hans Reitzel, København, 264-283.

2013 “At være dansk i udlandet - en religionssociologisk profil”, Religion. Tidsskrift for Religionslærerforeningen for Gymnasiet og HF, nr. 2, 38-50.

Kühle, Lene

2006 Moskeer i Danmark - islam og muslimske bedesteder, Univers, Højbjerg.

Levitt, Peggy

2007 God Needs No Passport. Immigrants and the Changing American Religious Landscape, The New Press, New York.

Mullins, Mark

1987 "The Life-Cycle of Ethnic Churches In Sociological Perspective", Japanese Journal of Religious Studies $14,321-334$

Møller, Erik Dybdal

2007 Danskere som indvandrere. Det dansk-argentinske eksempel, Poul Kristensens Forlag, Hellebæk.

Portes, Alejandro \& József Böröcz

1989 "Contemporary Immigration: Theoretical Perspectives On Its Determinants And Modes Of Incorporation", International Migration Review 23, 606-630.

Simonsen, Henrik Bredmose

1990 Kampen om danskheden. Tro og nationalitet i de danske kirkesamfund i Amerika, Aarhus Universitetsforlag, Århus.

Warburg, Margit

2006 Citizens of the World. A History and Sociology of the Baha'is from a Globalisation Perspective, Brill, Leiden.

2012a "Når det hellige og det verdslige rum smelter sammen. Danske kirker i udlandet og en dansk offentlig sfære", Religionsvidenskabeligt Tidsskrift 58, 21-32.

2012b "Den danske religionsmodel i den store vide verden", in: Lisbet Christoffersen, Hans Raun Iversen Niels Kærgård \& Margit Warburg, eds., Fremtidens danske religionsmodel, Anis, København, 55-70.

2013 “An Alternative National-Religious Space: The Danish Seamen's Church in Singapore”, in: Jens Dahl 
\& Esther Fihl, eds., A Comparative Ethnography of Alternative Spaces, Palgrave Macmillan, New York, 151-174.

Warner, R. Stephen

1998a "Immigration and Religious Communities in the United States", in: R. Stephen Warner \& Judith G. Wittner, eds., Gatherings in Diaspora. Religious Communities and the New Immigration, Temple University Press, Philadelphia, 3-34.

1998b "Religion and Migration in the United States", Social Compass 45, 123-134.

Yang, Fenggang \& Helen Rose Ebaugh

2001 "Transformations in New Immigrant Religions and Their Global Implications", American Sociological Review 66, 269-288.

Margit Warburg, professor, dr. phil. Institut for Tværkulturelle og Regionale Studier, Københavns Universitet 